\title{
Ocena powtarzalności obrzeża wycisków czynnościowych bezzębnej żuchwy z wykorzystaniem skanera optycznego
}

\author{
Assessing repeatability for the edges of functional impressions \\ in cases of edentulous mandibles using an optical scanner
}

Klinika Rehabilitacji Narządu Żucia, Uniwersytet Medyczny im. Karola Marcinkowskiego w Poznaniu

DOI: http://dx.doi.org/10.20883/df.2016.6

\begin{abstract}
Streszczenie
Wstęp. Wycisk czynnościowy jest istotnym etapem wykonawstwa protez całkowitych. Zarówno technika pobierania wycisku, jak również dobór odpowiedniego materiału wyciskowego mają szczególne znaczenie przy wycisku bezzębnej żuchwy z uwagi na znaczne ograniczenie pola protetycznego oraz dłuższe, w porównaniu z bezzębną szczęką, obrzeże. Dobranie rodzaju materiału wyciskowego do techniki wyciskowej pozwala na uzyskanie optymalnego zasięgu obrzeża, przez co stwarza warunki dla utrzymania protezy w jamie ustnej.

Cel. Porównanie zdolności powtarzalnego odtwarzania obrzeża wycisku czynnościowego żuchwy pobranego masą silikonową oraz masą żywiczo-woskową na łyżce indywidualnej z wyciskiem pobranym materiałem do biologicznej odnowy tkanek tissue conditioner na użytkowanej przez pacjenta protezie.

Materiał i metody. Do badań zakwalifikowano 19 pacjentów z bezzębiem w żuchwie i szczęce o wyrostku zębodołowym zanikłym w stopniu umiarkowanym (I typ wg Supple'a). Na modelu anatomicznym żuchwy wykonywano łyżkę indywidualną z akrylu, testowano ją w jamie ustnej z użyciem testów Herbsta. Tak przygotowaną łyżkę powielano dziesięciokrotnie, uzyskując 11 jednakowych łyżek. Na gotowej protezie żuchwy, po okresie adaptacyjnym (2 tygodnie), pobierano pięciokrotnie wycisk 24-godzinny z użyciem masy do biologicznej odnowy tkanek tissue conditioner Visco-gel. Wszystkie wyciski odlewano gipsem odlewowym klasy III. Modele poziomowano i cięto w poprzek wyrostka zębodołowego uzyskując z jednego modelu 12 przekrojów. Każdy przekrój skanowano na skanerze optycznym w rozdzielczości 1000 dpi. Zeskanowny przekrój poddawano obróbce w programie Microsoft Paint. Wyniki poddano analizie statystycznej.

Wyniki. Spośród badanych materiałów masa żywiczo-woskowa wykazuje największą tendencję do powtarzalnego odtwarzania obrzeża wycisku żuchwy. Masa typu tissue conditioner wykazuje znacząco mniejszą powtarzalność.

Wnioski. Materiał wyciskowy pozwalający na długie, precyzyjne kształtowanie wycisku czynnościowego pod kontrolą lekarza daje lepsze rezultaty dotyczące powtarzalności niż materiał kształtowany tylko i wyłącznie przez pacjenta, nawet pomimo zastosowania bardzo długiego czasu formowania.
\end{abstract}

Słowa kluczowe: wycisk czynnościowy, powtarzalność, skanowanie.

\begin{abstract}
Introduction. Obtaining a functional impression is an important stage in the process of manufacturing complete dentures. Proper matching of the impression material to the impression technique facilitates obtaining the optimal denture periphery, thereby providing suitable conditions for retaining the denture in the mouth.

Aim. The objective of the study was to compare the reproducibility of the border of a functional impression of an edentulous mandible taken in a custom tray with wax or silicone impression materials with those obtained with tissue conditioning material placed on a patient's own denture.

Material and methods. 19 patients with edentulous mandibles and moderate atrophy of the alveolar process (Supple type I) were chosen for inclusion in the study. Custom trays were made and then tested in the patient's mouth using the Herbst method. After the patient had worn this final denture for a minimum period of two weeks, Visco-gel tissue conditioner material was placed and the patient wore the denture for 24 hours, after which it was used to make a cast. All impressions obtained from the three materials were cast in dental stone (type III). The casts were levelled and sliced perpendicularly to the line of the alveolar process. 12 sections of each cast were obtained. Every slice was scanned at a resolution of $1000 \mathrm{dpi}$. The scanned pictures were processed with Microsoft Paint. The results were statistically analysed.

Results. Wax impression material demonstrated the highest tendency for repeatable recording of the border of the impression. The tissue conditioner material showed significantly less repeatability.

Conclusions. The use of an impression material which produces a functional, precise cast appeared to give better results as regards repeatability than a material formed only by the patient, in spite of being in situ for a long time during the forming.
\end{abstract}

Keywords: functional impression, repeatability, scanning. 


\section{Wstęp}

Technika wykonania protez całkowitych pozostaje ta sama od dziesięcioleci i polega w pierwszej fazie na prawidłowym pobraniu wycisku czynnościowego, nie tylko odwzorowującego pole protetyczne w sposób statyczny, ale przede wszystkim kształtującego obrzeże protezy pod względem czynnościowym.

Badania Muraty i wsp. [1-7] oraz McCarthy'ego i Mosera [8-10] wykazały istotne znaczenie dla jakości wycisku czynnościowego następujących cech: utrzymanie stałości wymiarów liniowych i objętościowych, odpowiednie właściwości reologiczne, czyli zdolność do płynięcia i odwzorowywania pola protetycznego, odpowiednia odporność mechaniczna w trakcie przebywania w jamie ustnej, brak reakcji z gipsem, a także otrzymanie gładkiej powierzchni modelu.

W wycisku czynnościowym istotne jest zastosowanie odpowiedniego materiału wyciskowego. Różnorodność dostępnych mas wyciskowych sprawia, że ważną rolę odgrywa znajomość właściwości fizycznych i sposobu zachowania się materiału w jamie ustnej, a co za tym idzie zdolności do dokładnego odtworzenia pola protetycznego ze szczególnym uwzględnieniem jego obrzeża. Jedną z metod oceny jakości wycisku czynnościowego może być określenie jej zdolności do powtarzalnego odtwarzania obrzeża [11].

\section{Materiał i metody}

Do badań wybrano 19 osób w wieku od 51 do 70 lat, u których występowało bezzębie zarówno w szczęce, jak i w żuchwie. Podstawę kwalifikacji stanowiło spełnienie następujących kryteriów ustalonych podczas badania klinicznego:

- jama ustna typu I wg Supplégo [12], czyli z dobrze zachowanymi wyrostkami zębodołowymi, przyczepami mięśniowymi daleko od grzbietu wyrostka i z błoną śluzową o przeciętnej podatności,

- wyrostki zębodołowe zanikłe w stopniu umiarkowanym, bez balotującego grzbietu,

- zdrowa błona śluzowa o przeciętnej podatności,

- brak zachyłków w obrębie wyrostka zębodołowego,

- brak zmian chorobowych w obrębie stawów skroniowo-żuchwowych i mięśni narządu żucia. Do badań wybrano dwa materiały: masę żywiczo-woskową EX-3-N Gold (J. Meist, Niemcy) oraz materiał do biologicznej odnowy tkanek Visco-gel (Dentsply, Niemcy) o odmiennych właściwościach fizyko-chemicznych.

U każdego pacjenta wykonano wyciski anatomiczne masą alginatową Kromopan (Lascod, Włochy). Następnie na modelach anatomicznych wykonano łyżki wyciskowe indywidualne: dla szczęki z szelaku, dla żuchwy z akrylanowego tworzywa szybkopolimeryzującego Duracrol (Spofa Dental, Czechy).

W czasie kolejnej wizyty testowano wykonane łyżki w jamie ustnej pacjenta metodą Herbsta, aż do momentu wyeliminowania wyważającego działania otaczających mięśni. W celu przeprowadzenia doświadczenia dokonano dziesięciokrotnego powielenia wyciskowej łyżki indywidualnej dla żuchwy w masie agarowej Microform (Schütz Dental, Niemcy), uzyskując w ten sposób łącznie 11 jednakowych łyżek. Dziesięć z nich posłużyło do pobrania wycisków doświadczalnych użytych w badaniach, natomiast jedenasta wykorzystana została do wykonania protezy.

Kolejnym etapem badań było pobieranie wycisków techniką Herbsta (przy ustach otwartych) na dziesięciu wcześniej przygotowanych łyżkach indywidualnych. Do wycisków na łyżkach indywidualnych użyto dwóch rodzajów mas wyciskowych: termoplastycznej żywiczo-woskowej Ex-3-N Gold (J. Meist, Niemcy) i, jako grupy kontrolnej, elastomerowej silikonowej masy kondensacyjnej Stomaflex Pasta (Spofa Dental, Czechy), które w dalszej części pracy oznaczano odpowiednio literami EG i SF. Podczas jednej wizyty pobierano jeden wycisk EG i jeden wycisk SF. Łącznie podczas pięciu wizyt pobrano 5 wycisków EG i 5 wycisków SF, co daje w sumie 10 wycisków na łyżkach indywidualnych. Jednocześnie prowadzono pełen cykl kliniczny i laboratoryjny wykonawstwa jednego kompletu całkowitych protez dla szczęki i żuchwy. Po ich osadzeniu w jamie ustnej pacjenta i upływie dwutygodniowego okresu adaptacyjnego przystępowano do kolejnego etapu badań, jakim było pobieranie wycisku czynnościowego 24-godzinnego przy użyciu masy do biologicznej odnowy tkanek (tissue conditioner) Visco-gel (Dentsply, Niemcy) określanej dalej skrótem VG. W tym celu wstępnie obniżano i zwężano obrzeże protezy, zeszlifowując je na głębokość $2 \mathrm{~mm}$. Protezę z materiałem osadzano w jamie ustnej i zalecano pacjentowi używanie jej przez 24 godziny w celu formowania obrzeża wycisku. Następnie odlewano model gipsowy wykorzystywany do dalszych badań. Protezę dokładnie oczyszczano z nałożonej poprzednio warstwy VG i aplikowano nową warstwę tego samego materiału na kolejne 24 godziny. Procedury te powtarzano do momentu uzyskania 5 modeli gipsowych. Następnie protezę podścielano ostatecznie metodą pośrednią i zwracano pacjentowi. W ten sposób uzyskiwano łączną liczbę 15 modeli gipsowych pochodzących od jednego pacjenta, według następującego schematu: 5 modeli z wycisku SF na łyżce indywidualnej, 5 modeli z wycisku EG na łyżce indywidualnej, 5 modeli z wycisku VG na protezie.

Wszystkie wyciski odlewano przy użyciu gipsu odlewowego III klasy (Schütz Dental, Niemcy), z wytworzeniem brzegu modelu roboczego $4 \mathrm{~mm}$ powyżej obrzeża wycisku, przez co minimalna 


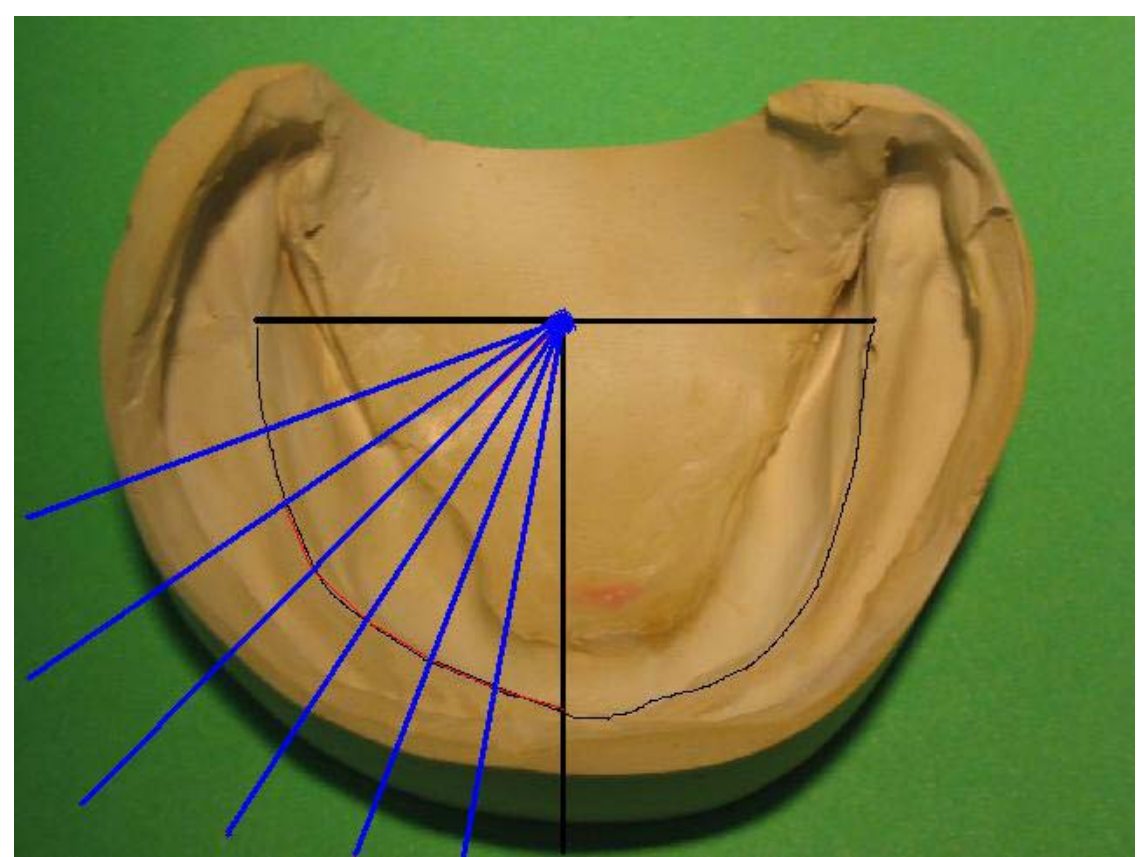

Rycina 1. Linie cięcia dla strony prawej modelu gipsowego bezzębnej żuchwy Figure 1. Cutting lines for the right side of the cast of edentulous mandible

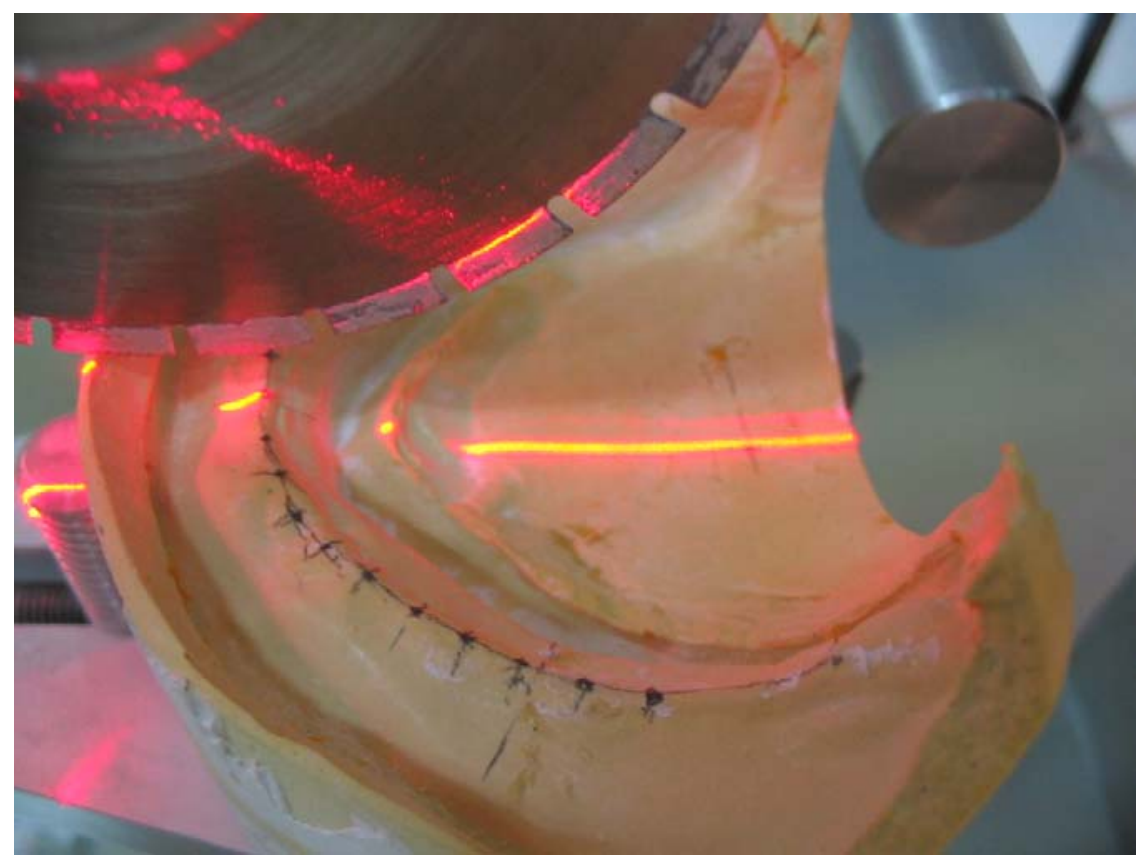

Rycina 2. Uwidocznienie prowadzenia laserowego piły Unimat (Reitel, Niemcy) na modelu żuchwy

Figure 2. Visualization of the laser guide of the Unimat saw (Reitel, Germany) on a model of the mandible

głębokość rowka powstałego po uwolnieniu wycisku wynosiła również $4 \mathrm{~mm}$. W celu wytworzenia płaszczyzny odniesienia do późniejszych pomiarów, modele gipsowe poddano poziomowaniu wykorzystując odpowiedni przyrząd. Kolejnym etapem było wyznaczenie linii cięcia modelu gipsowego w celu uzyskania poprzecznych przekrojów przez wyrostek zębodołowy i wytworzoną rynienkę odpowiadającą obrzeżu wycisku czynnościowego (Rycina 1).
Modele cięto używając piły do cięcia modeli segmentowych Unimet (Reitel, Niemcy) wyposażonej w prowadzenie laserowe tarczy tnącej (Rycina 2).

Uzyskane przekroje skanowano przy użyciu skanera optycznego Plustek Optic Pro ST24 (Plustek, USA) w rozdzielczości 1000 pikseli. Każdy przekrój zapisywany był w oddzielnym pliku BMP (mapa bitowa Windows), a następnie poddawany obróbce w programie Microsoft Paint dającym 


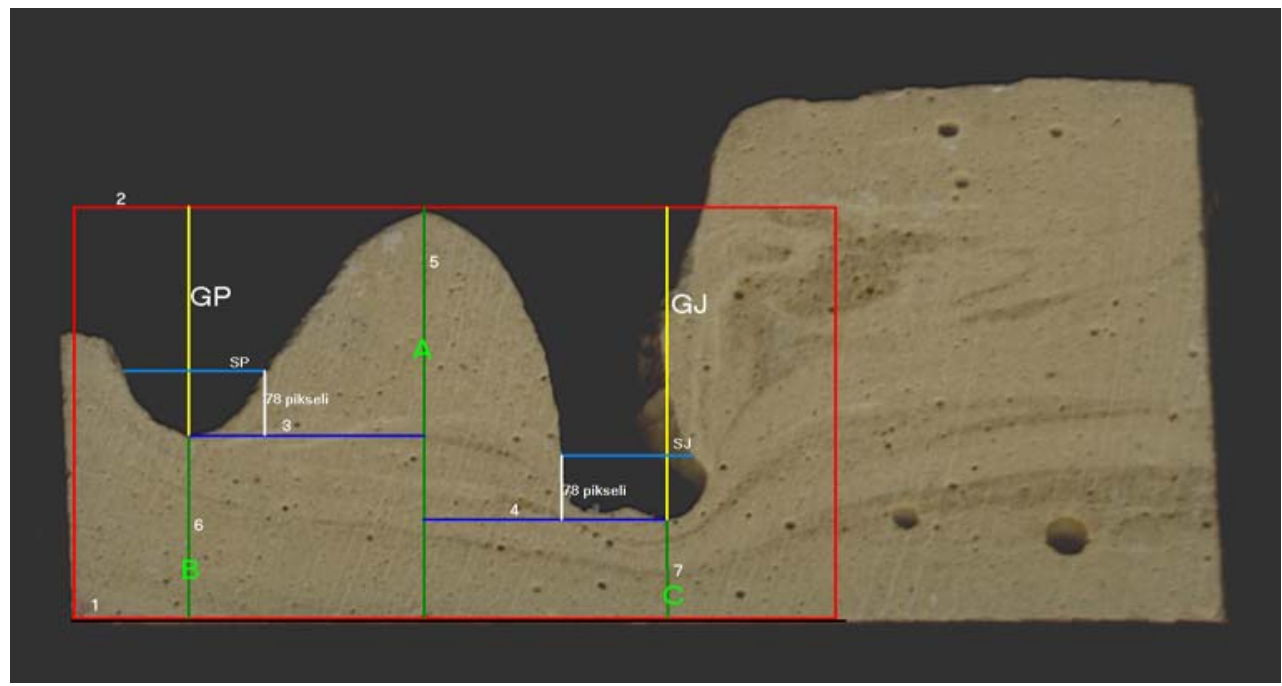

Rycina 3. Obraz przekroju poprzecznego modelu gipsowego uzyskany za pomocą skanera

Figure 3. The image of a cross section of a cast obtained with the scanner

możliwość mierzenia wybranych wymiarów rowka bez konieczności użycia mikroskopu optycznego.

Po wyznaczeniu linii pomocniczych przeprowadzono pomiary głębokości i szerokości rynienki (Rycina 3) według następujących kryteriów:

A - odległość od podstawy modelu do najwyższego punktu wyrostka zębodołowego,

B - odległość od podstawy modelu do najniższego punku rynienki od strony przedsionkowej,

C - odległość od podstawy modelu do najniższego punku rynienki od strony językowej,

GP- głębokość rynienki od strony przedsionkowej (A-B),

GJ-głębokość rynienki od strony językowej (A-C),

SP - szerokość rynienki po stronie przedsionkowej na poziomie 78 pikseli powyżej najniższego punktu rynienki,

SJ - szerokość rynienki po stronie językowej na poziomie 78 pikseli powyżej najniższego punktu rynienki.

Wartości bezwzględne wyników pomiarów przedstawione zostały w pikselach. W celu przeliczenia ich na jednostki metryczne należy przyjąć następujące parametry: 1 piksel w rozdzielczości $1000 \mathrm{dpi}=0,025 \mathrm{~mm}$, co oznacza, że $1 \mathrm{~mm}$ równy jest 40 pikselom.

\section{Wyniki}

Zastosowanie wybranego modelu badawczego wymagało przekształcenia bezwzględnych wartości wyników wyrażonych w pikselach w wartości względne, umożliwiające porównanie otrzymanych wyników.

W tym celu wprowadzono następujące wartości: wskaźnik różnicy i międzyosobniczą zmienność wskaźnika różnicy. Analizy statystyczne przeprowadzono używając arkusza kalkulacyjnego Microsoft Excel.
W wyniku przeprowadzonych pomiarów uzyskano łączną liczbę 13680 wyników dla 19 przebadanych pacjentów. Bezwzględne wartości pomiarów jak i przeprowadzona analiza statystyczna pozwalają stwierdzić, że badane materiały wyciskowe prezentują różną zdolność do powtarzalnego odtwarzania analizowanej charakterystyki struktur jamy ustnej graniczących z obrzeżem przyszłej całkowitej dolnej protezy podczas pobierania wycisku czynnościowego.

Najlepsze właściwości, ze względu na badaną przez autorów cechę, posiada masa żywiczo-woskowa Ex-3-N Gold. Materiały Stomaflex i Visco-gel wykazują zbliżoną wartość powtarzalności, jakkolwiek niższą od masy wymienionej wcześniej.

Biorąc pod uwagę miejsce przekroju, dla mas Stomaflex i EX-3-N Gold daje się zauważyć tendencję do zmniejszania się powtarzalności w miarę przesuwania się od linii pośrodkowej ciała w kierunku wyniosłości gruszkowatych. Visco-gel nie wykazuje takiej właściwości, prezentując podobne wartości wskaźnika różnicy na całej długości modelu wyrostka zębodołowego poddanego przekrojom.

Uwzględniając wymiary przekrojów, największą powtarzalność zaobserwować można w odniesieniu do głębokości rynienki zarówno od strony przedsionkowej jak i językowej dla masy Ex-3-N Gold; dla masy Stomaflex wartości głębokości i szerokości rynienki są porównywalne, natomiast masa Visco-gel prezentuje większą powtarzalność szerokości rynienki niż jej głębokości.

\section{Dyskusja}

Wyniki przeprowadzonych badań wskazują, że metoda wycisku czynnościowego z zastosowaniem testów Herbsta pozwala na zachowanie większej powtarzalności odtworzenia obrzeża 
wycisku czynnościowego bezzębnej żuchwy niż metoda pobierania wycisku czynnościowego przy ustach zamkniętych na własnej protezie pacjenta. Zgadza się to z wnioskami badań prowadzonych wcześniej przez Krysińskiego i Prylińskiego [13] oraz Wiznerowicza [14]. Większa powtarzalność zaobserwowana dla materiału Ex-3-N Gold prowadzi do konkluzji, że materiał plastyczny w temperaturze jamy ustnej i nieograniczony czasem wiązania bardziej powtarzalnie niż dwie inne badane masy rejestruje przemieszczenia otaczających tkanek podczas wykonywania ruchów czynnościowych. Prawdopodobnie istotne znaczenie mają również właściwości fizykochemiczne materiału. Biorąc pod uwagę, że wspomniane wcześniejsze badania potwierdziły zdolność do powtarzalnego odtwarzania sytuacji klinicznej $w$ jamie ustnej przez każdy $z$ badanych materiałów, wydaje się, że podstawowe znaczenie dla charakterystyki tego parametru ma technika pobierania wycisku czynnościowego. Potwierdzenie tym samym znajduje spostrzeżenie Wiznerowicza [14], że metodą wycisku bezzębnej szczęki przy ustach zamkniętych uzyskuje się mniejszą powtarzalność niż przy ustach otwartych. Wycisk wykonywany z udziałem lekarza protetyka pozwala na lepszą kontrolę tego procesu. Poza możliwością instruowania pacjenta oraz zwracania uwagi na poprawność wykonywania testów czynnościowych istnieje również możliwość określenia stopnia nacisku na łyżkę indywidualną. Generowane jest w ten sposób ciśnienie adekwatne do zastosowanego materiału wyciskowego. Zwrócili na to uwage Weng i Khlevnoy [15] w swoich badaniach. Stosując metodę przy ustach zamkniętych, pobierając zarazem wycisk na protezie przez dłuższy okres czasu, lekarz nie ma wpływu na wyzwalane przez pacjenta siły mięśniowe. Cechy fizyczne materiału związane z jego zdolnością do płynięcia są natomiast stałe, a więc wielkość siły przyłożonej do powierzchni materiału wyciskowego $w$ trakcie formowania wycisku także wpływa na kształt ostatecznego odwzorowania. Zatem uzasadnione wydaje się twierdzenie, że brak kontroli nad procesem pobierania wycisku czynnościowego prowadzi do niedających się powtórzyć, przypadkowych odwzorowań obrzeża. Ciekawe badania, mające bezpośrednie odniesienie do wcześniejszych wniosków, przeprowadził Hasanreisoglu ze wsp. [16]. Porównali oni metodę pobierania wycisku czynnościowego przez lekarza z metodą formowania wycisku stymulowanie nerwów ruchowych za pomocą bodźców elektrycznych metodą TENS, przy biernej postawie pacjenta. Większą powtarzalność wycisków uzyskano stymulując gałęzie nerwowe bodźcami elektrycznymi. Można więc zaryzykować stwierdzenie, że im większa swoboda pozostawiona jest pacjentowi podczas pobierania wycisku, tym mniejszego poziomu powtarzalności możemy oczekiwać.
Poza wnioskami płynącymi z fizykochemicznych właściwości badanych materiałów obserwowano także różnice w zakresie powtarzalności w zależności od miejsca przekroju modelu gipsowego. Przedni odcinek wyrostka zębodołowego cechował się większą powtarzalnością niż odcinki boczne, co bardziej widoczne było po stronie językowej. Jest to najprawdopodobniej związane z przebiegiem włókien mięśni żujących i mimicznych biorących udział $w$ rozdrabnianiu pokarmu i jego połykaniu, ale również z techniką wyciskową, ponieważ w przypadku wycisku na protezie w czasie 24 godzin przy ustach zamkniętych taka zależność nie została zauważona.

\section{Wnioski}

1. Zastosowanie masy silikonowej, a zwłaszcza żywiczo-woskowej pozwala na powtarzalne odwzorowanie ułożenia miękkich tkanek sąsiadujących z obrzeżem wycisku czynnościowego bezzębnej żuchwy.

2. Metoda pobierania długoczasowego (wielogodzinnego) wycisku czynnościowego bezzębnej żuchwy przy ustach zamkniętych przy zastosowaniu masy typu tissue conditioner cechuje się małą powtarzalnością obrzeża i ustępuje metodzie wyciskowej według Herbsta z zastosowaniem konwencjonalnych materiałów wyciskowych.

3. Głębokość i szerokość rowków odpowiadajacych obrzeżu wycisku czynnościowego zależy w większym stopniu od użytej masy wyciskowej niż od techniki wycisku.

4. Technika wycisku przy ustach otwartych pozwala na uzyskanie większej powtarzalności obrzeża w przednim odcinku bezzębnego wyrostka niezależnie od użytego $\mathrm{w}$ badaniach materiału wyciskowego.

\section{Oświadczenia}

Oświadczenie dotyczące konfliktu interesów

Autorzy deklarują brak konfliktu interesów w autorstwie oraz publikacji pracy.

\section{Źródła finansowania}

Autorzy deklarują brak źródeł finansowania.

\section{Piśmiennictwo}

[1] Murata H, Kawamura M, Hamada T, Saleh S, Kresnoadi $\mathrm{U}$, Toki K. Dimentional stability and weight changes of tissue conditioners. J Oral Rehabil. 2001;28(10):918-923.

[2] Murata H, Hamada T, Harshini H, Toki K, Nikawa H. Effect of addition of ethyl alcohol on gelation and viscoelasticity of tissue conditioners. J Oral Rehabil. 2001;28(1):48-54.

[3] Murata H, Hamada T, Nikawa H, Djulaeha E. Rheology of tissue conditioners. J Prosth Dent. 1998;79(2):188-199.

[4] Murata H, Hamada T, Toguchi N, Shigeto N, Nikawa H. Viscoelastic properties of tissue conditioners - influence of molecular weight of polymer powders and powder/ liquid ratio and the clinical implications. J Oral Rehabil. 1998;25(8):621-629. 
[5] Murata H, Hong G, Li YA, Hamada T. Compatibility of tissue conditioners and dental stones: Effect on surface roughness. J Prosth Dent. 2005;93(3):274-281.

[6] Murata H, Iwanaga H, Shigeto N, Hamada T. Initial flow of tissue conditioners - influence of composition and structure on gelation. J Oral Rehabil. 1993;20(2):177-187.

[7] Murata H, McCabe JF, Jepson NJ, Hamada T. The influence of immersion solutions on the viscoelasticity of temporary soft lining materials. Dent Mat. 1996;12(1):19-24.

[8] McCarthy JA, Moser JB. Tissue conditioning and functional impression materials and techniques. Dent Clin North Am. 1984;28(2):239-251.

[9] McCarthy JA, Moser JB. Tissue conditioners as functional impression materials. J Oral Rehabil. 1978;5(4):357-364.

[10] McCarthy JA, Moser JB. Undercut reproducibility of functional impression materials (tissue conditioners). J Oral Rehabil. 1978;5(3):287-292.

[11] Krysiński Z, Pryliński M. Reproducibility of the border outline of working impressions of the edentulous mandible obtained by the Slack-Herbst method. J Nihon Univ Sch Dent. 1986;28(2):139-145.

[12] Spiechowicz E. Protetyka stomatologiczna. Wydanie III. Wydawnictwo Lekarskie PZWL, Warszawa 1994.

[13] Krysiński Z, Pryliński M. Reproducibility of the border outline of working impressions of the edentulous mandible obtained by the Slack-Herbst method. J Nihon Univ Sch Dent. 1986;28(2):139-145.
[14] Wiznerowicz W. Powtarzalność zarysów obrzeża czynnościowych wycisków bezzębnej szczęki wykonanych metodą Herbsta i metodą przy ustach zamkniętych w trakcie żucia. Praca doktorska. Poznań 1994

[15] Weng BX, Khlevnoy V. Pressure control for complete denture impressions. Oral Health. 1995;85(11):21-27.

[16] Hasanreisoglu U, Gurbuz A, Ozden AN, Kesim F. Evaluation of reproducibility of the peripheral tissues in edentulous patients. Tr J of Medical Sciences. 1998;28(3):291294.

Zaakceptowano do edycji: 2016-04-28 Zaakceptowano do publikacji: 2016-05-06

Adres do korespondencji:

Collegium Stomatologicum

ul. Bukowska 70, 60-812 Poznań

e-mail: mariusz.glapinski@gmail.com 